\title{
SANAL DÜNYADA SANAL DÖNÜŞÜM
}

\author{
Laman İSMAYILZADA \\ İstanbul Aydın University, İstanbul \\ ismayilzade_1@mail.ru
}

\begin{abstract}
ÖZ
Günümüzde internet kullanımının geniş yayılması büyük bir etkileşim alanının ortaya çıkmasına yol açmıştır. Her geçen gün internet, sosyal ağlar hayatımıza daha çok dahil olmaktadır ki, bu da farklı bir dünyanın-sanal dünyanın ortaya çıkmasına yol açmaktadır. Sanal dünyanın ortaya çıkması sanal kimliklerin da oluşumunu gerektirmektedir. Sanal bir dünyada farklı kimliklerin oluşumu, farklı kimliklere dönüşüm kaçınılmazdır. Araştırmanın amacı sanal dünyada kimlik oluşumunun incelenmesi, bu sürecin açıklanmasıdır. Sanal dünya ve kimlik dönüşümü kavramları incelenerek bu dönüşüm sürecinin sebep ve özellikleri açıklanmaktadır. Sanal ve gerçek dünya arasındakı farkı açıklayabilmek için Black Mirror (Siyah ayna) dizisinin Be Right Back (Hemen Dön) adlı bölümü incelenecektir. Dizide gerçek ve sanal arasındaki farklar açıklanmıştır ve bu farklılıkların sebepleri belirtilmiştir.
\end{abstract}

Anahtar kelimeler: Internet, sosyal medya, kimlik, etkileşim

\section{VIRTUAL TRANSFORMATION IN THE VIRTUAL WORLD}

\begin{abstract}
Today, the widespread use of the internet has led to the creation of a large field of interaction. With each passing day, the internet, social networks are becoming more and more involved in our lives, which has allowed for the creation of a different world - the virtual world. The trick of a virtual world is that it's a virtual identity. In a virtual world, the formation of different identities, conversion to different identities is inevitable. The study of identity formation in the virtual world of our research is the announcement of this process. The concepts of virtual world and identity transformation were examined and the reasons and features of this transformation process were explained. The concepts of virtual world and identity transformation will be examined and the reasons and features of this transformation process will be explained. To explain the difference between the virtual world and the real world, the Black Mirror series' Be Right Back section was examined. The differences between the real and the virtual were explained and the reasons for these differences were indicated.
\end{abstract}

Keywords: Internet, social media, identity, interaction

\section{GİRIŞ}

İletişim teknolojilerinin gelişimi zaman ve mekan kavramlarının yanı sıra günümüzde kimlik kavramının da dönüşümüne yol açmıştır. İletişim teknolojileri ve internet ağlarının ortaya çıkması hem geri kazanılan zaman ve mekan, hem de idealize edilmiş, yaşanılan değil, yaşanılmasının hayal edildiği farklı kimliklerin oluşumuna yol açmıştr. Gerçek kimliklerin simge ve avatarlara bağlı olarak sürdürülmesi var olduğumuz gerçek dünya dışında, sosyal ağlar vasıtasıyla var olduğumuz sanal dünyanın da paralel olarak sürdürüldüğünü gösterir.

Deleuze, dış dünyanın kaçak ihlaller yaptığı dünyayı sanal dünya olarak tanımlamıştır (Deleuze, 2014: 59). Baudrillard’da sanal dünya tarafından silinen bir dünyada yaşadığımızı söylemiştir. Yani gerçeklik yerine görüntülerin önem taşıdığı bir dünya ortaya çıkmıştır. Bu dünyada var olanın kabullenilmesi zorunluluğu yoktur. Yeni, idealize edilmiş, mükemmelleştirilmiş bir kimliğin ortaya çıkması var olanla yaşama zorunluluğunu ortadan kaldırmışdır ki, bu da sanal dünyanın vatandaşlarının sayının artmasına neden olmuştur.

Sanal dünyanın sunduğu yasaklardan uzak bir dünya, yapılacakların veyaşanacakların hayat şartlarına değil hayal gücüne bağlı olarak sürdürülmesi, dönüşen kimliklerin dış dünyamıza ters oluşumu, 
sağlanan kolaylıkların yanı sıra, real dünyaya adapte olmada sorunlar yaratabilir. Bireylerin kimlik dönüşümleri bulundukları toplumun sosyal ve kültürel yapılarına göre farklılık gösterebilir. Sanal dünyada kendilerini ifade edebilmek için bireyler sanal kimliklere bürünebilmektedir.

Araştırmanın amacı sanal dünyada kimlik oluşumunun incelenmesi, bu sürecin açıklanmasıdır. Sanal dünya ve kimlik dönüşümü kavramları incelenerek bu dönüşüm sürecinin sebep ve özellikleri açıklanmaktadır. Sanal hayatın gerçek dünyaya adapte olamama sebeplerinin açıklanmasıda çalışmanın genel amaçlarındandır. Sanal dünyanın bireylere sağladığı sonsuz imkanların bireyler üzerindeki etkisi açıklanarak, bireylerin kimliklerini değiştirme sebeplerinin açıklanması amaçlanmıştır. Dış dünyayla iç dünyanın karşılaştııılması yapılarak, bireylerin görsel olarak belirlenmiş bir kimliğin dışına çıkma durumları da araştırılacaktır.

Çalışmamızda genel olarak sanal dünya ve kimlik dönüşümü kavramları incelenecektir. Kimlik dönüşümlerinin genel olarak daha fazla yaşandığı sosyal medya mecraları belirtilerek, kimlik dönüşümlerinin amacı ve sonuçları açıklanacaktır. Verilerin toplanılması için sanallık ve kimlik kavramları ile ilgili literatürlerin yanı sıra internet siteleri incelenecektir. Sosyal medya mecralarında oluşmuş kimlikler üzerine yorumlar yapılacaktır.

Kimlik dönüşümü sürecini Baudrillard'ın simülasyon kuramı ile anlatmaktadır. Bu kuramın temel konusu olmayan bir şeyi var gibi gösterebilmektir. Simülasyon evreni, görünümler evrenidir ya da bir caydırma eylemidir. Caydırmanın en önemli kozu görüntü, ses ve sözü bir arada kullanan medyadır (Özer, 2011 : 34). Araştırmamızda sanal dünya ve gerçek dünyanın benzer ve farklılıklarını gösteren Black Mirror (Siyah ayna) dizisinin Be Right Back (Hemen Dön) adlı bölümü incelenmiştir. Filmde sanal dünyanın ortaya çıkma sebepleri, bu dünyaya bağlı yaşamın sonuçları ve sanal dünyanın gerçek olamaması sebepleri gösterilmiştir. Var olan dünyaya dahil olmuş sanal bir dünya ve o sanal dünyaya aktarılmış gerçek bilgilerin sanal olarak yeniden gerçek dünyaya simüle edilmesi açıklanması gereken önemli konulardandır.

\section{SANAL KİMLIK}

Kimlik bireylerin yaşamlarında hem kültürel, hem sosyal olarak sergiledikleri davranışların bütünüdür. Kimliğin oluşumuna genel olarak etki eden etkenler bireyin ilk yıllar aile içi, daha sonra okulda ve işyerinde yaşadığı etkileşim sürecidir. Bu etkenler benliklerin oluşumunda önemli rol oynamaktadır. $\mathrm{Bu}$ etkenler bireylerin her zaman kazanmak istedikleri benlikleri elde etmelerine izin vermemektedir. Henri Taifel in "Sosyal kimlik teorisi”ne göre belirli bir rolü ifade edebilen davranışlarının arasında veya içinde tercih yapmak, kişinin, bu rollerle ilgili kimlikler hiyerarşisindeki konumunu yansitmaktadır.

Sanal dünya ise bireylere kendi istedikleri kimliklerini oluşturmakta yardımcı olur. Oluşmuş sanal kimlikler her zaman bireylerin gerçek hayatta var olan benlikleri değil, olumlu bilgilerini aktardıkları kimliklerdir. Kısacası, sanal kimlikleri kendilerini ifade etme biçimleridir. Baudrillard’a göre bu durum gerçeğin sahte temsilcisi olan simulasyonların çoğalmasıdır (Baudrillard, 1991: 80).

Gerçek hayatta beden ve ruh olarak tek bir mekanda var olmamız sanal kimliğin önemini artırır. Sanal kimlikde zaman ve mekan anlayışı yoktur. Sadece zaman ve mekan anlayışı değil, dil, din, ırk olarak seçimler sınırsızdır ve sanal kimlik hayal gücüne dayanarak var olabilir. Var olanı değil, var olması gerekeni yansıtan sanal kimlikler idealize edilmiş kimliklerdir. Gerçek hayatta yaşadığı dezavantajların sanal hayata taşınmaması sanal kimliklerin idealize edilmiş kimlikler olduğunu göstermektedir. Sosyal hayatta ve gerçek ilişkilerde başarılı olamayan kişiler sanal kimliklere bürünerek sanal hayatta başarılı olmaktadırlar.

Sanal kimliklerin ortaya çıkma sebebi bireylerin ekonomik ve sosyal kaçışları ya da cinsiyet ayrışım sorunları olabilir. Gerçek hayatta toplumsal baskıdan korkarak saklamak zorunda kaldıkları duyguları sanal dünyada rahatca ifade edebilmeleri sanal kimliklerin oluşmasına etki eder. Çeşitli sanal kimlik türleri, çeşitli platformları ve sanal alanları tamamlamak üzere oluşturulmuştur. Video oyunları veya diğer mekanlarda en çok kullanılanlar "avatarlar" olarak adlandırılmaktadır. Bir avatar temsili 
görüntüleri profille ilgili isim ve sanal kimlik hakkında bilgi içermektedir. İnsanlar sanal kimlikleri kendilerinin sanal temsilcileri olarak kurarlar. Örneğin, bir çevrim içi rol yapma oyunu oynayan birinin sanal kimliği, kendi kimliğinden neredeyse tamamen farklıdır; ancak, bazı açılardan, kendi kimliğinin bir parçasıdır, çünkü tek tek oluşturulmuştur. Oluşturulma sürecinde seçilen götergeler bazen birey tarafindan elde edilmesi zor olan şeyler olabilir. Bu maddi ve manevi durumlarla bağli ola bilir ki, bunları sanal dünyada elde etmek bir komuta bağlıdır. Gerçek dünyada ise bunlar zaman istemektedir. Gerçek ve sanal kimlikler arasındaki fark bireyin gerçek veya sahte olduğunu göstermektedir. Bu gerçek ve sahte arasındaki farkı göstermektedir. Gerçek hayatta aynı durumla karşılaşıldığında avatara benzer bir kimliğe bürünmenin sebebi ise sanal kimliğin aslında gerçek kimliğin bir parçası olmasıdır.

Kavram olarak, sanal dünyalar ve platformlar daha işlevsel ve hareketli hale geldiğinde, sanal kimlikler de kendini ifade etmek için daha baskın hale gelmekteler. Sanal kimlik, çevrim içi iletişim kurarken ima edilen bir kişidir. Bu durum, çevrim içi olduğunuzda kim olduğunuzun algılanan bir görünümüdür. Çevrim içi kimlik, nispeten küçük gerçeklik düzeylerine sahip görseldir. Türk Dil Kurumunda "sanal" gerçekte yeri olmayıp zihinde tasarlanan bir olgu olarak açıklanmıştır. Sanal kimlikler de, çevrim içi kişilerin zihinlerinde canlandırarak yayınladığı kişilik, fiziksel açıklama ve kim olmak istediklerini gösterme becerisidir. Marx`a göre bu "kendi emeğine ve ürününe yabancılaşma" durumudur (Marx, 1993: 80 aktaran Kenan Somer). Geray`a göre ise "masaüstü sömürgecilik’tir (Geray, 1995:34).

Çevrim içi kimlik, kişinin daha zeki, daha seksi, daha pürüzsüz veya daha cesur görünmelerini sağlamak için yaratılmış bir kimliktir. Seçilen kişilik genellikle o kişinin sahip olduğu veya sunmak istediği kimliği gösterir. İletişim sistemlerinde çevrim içi kimliği kolaylaştırmak için, belirli çevrim içi kimliği yürütmek için bir 'sanal kimlik' oluşturulmalıdır. Anlatmakta olduğumuz dizide aktif internet kullanıcısı olan birinin veritabanında toplanan bilgilerinin insanın gerçek hayatta olmadığ zamanda bile sanal kimliğin gerçek hayata simüle edilmesi anlatılır. Sanal bellekte depolanmış bilgilere dayanarak sanal kimliğin gerçek hayata entegresi siyah ekranı aradan kaldırmıştır.

\section{SOSYAL MEDYADA DÖNÜŞEN KIMMLİKLER}

Sosyal medya kişilerarası iletişim ve etkileşimin çevrim içi olarak sürdürüldüğü sanal mekanlardır. kişilerin kendi düşüncelerini söyleyebildikleri ve dikkate alınacakları mekanlar olduğundan sosyal medya önem kazanmıştır. Mekanların sanal olmasına rağmen bireyler arası etkileşimi sağlaması büyük etki yaratmaktadır. Günümüz toplumunu gösteri toplumu adlandıran Debord, teknolojinin bireyleri yabancılaştırıp, sadece gösteri yapan bireylere dönüştürdüğünü belirtmiştir (Debord, 2006 : 41). Kısaca, teknolojinin gelişimi ile yeni medya artık bireylerin kendilerini ifade etme imkanı buldukları bir mekan haline gelmiştir. Gerçeklikten uzaklaşarak sahte bir kimliğe bürünen bireyler var oldukları değil, var olmak istedikleri kimliklere bürünmektedirler.

Sosyal medya bireylere özel alanlarda sadece sanal kimliklerle varlıklarını sürdürebilmelerine izin verir. $\mathrm{Bu}$ alanlar bireylerin kendi kimliklerinin, kendi yaşantılarının belirlibir kısmını sınırlı şekilde ifade ederek kendilerini tatmin ettikleri bir mecradır. Gerçek hayatta sergilemekte zorluk çektikleri davranış ve düşüncelerini sanal dünyada rahatlıkla görsel olarak kitlelere yansitılması sosyal medyada dönüşen kimliklerin gerçek kimliklerden farkını yansıtmaktadır. Bireylerin sanal kimliklere bürünme sebebinin sadece sahip olmak istedikleri kimlikler olmadığını söyleyebiliriz. Kendi düşüncelerini toplumsal baskılardan uzak özgür ifade edebilmeleri de yeni medyaya olan ilgiyi artırmaktalar.

Bireylerin sanal kimlikleri son zamanlarda en çok İnstagram, Facebook gibi sosyal medya mecralarda görülmektedir. Kişiyi sadece bu mecralarda paylaştığı görsel veyazılı iletilere göre tanıyabiliriz. Toplumsal etkileşim sonucunda sadece göstermek ve iletmek istediklerini paylaşarak sadece tanıtmak ve göstermek istediği kimliğini gördügümüzü anlamaktayız.

Sosyal medya bireylere zaman ve mekandan bağımsız olarak iletişim kurmalarına izin vermektedir. Bireyin kendini gösterebilme şeklinin her zaman çevrim içi olması bireyin sosyal ağlara olan ilgisini artırmaktadır. Gerçek hayatta gerçek kimliklerin yorulabilecegi, uyuyabileceği ihtimallerinin internette 
bulunmaması, gösterilmesi istenen kimliğin her zaman aktif ve çevrim içi olması sanal kimliğe olan ilginin sebebidir. Sanal kimliğin kullanıcılara sağladığı anonimleşme durumu sosyal medya ortamlarında bireylerin daha özgür olmalarına izin verir.

Gerçek hayatta sosyalleme problemi yaşayan bireyler daha fazla sosyal medya mecreları üzerinden sosyalleşebilirler. Sosyal medya bireylerin sanal dünyada var olmalarına, diğer kullanıcılarla etkileşim içinde iletişim kurmalarına izin verir. Avcıoğlu, sanal kimliklerin inşa edilmesinde siyaset, din, coğrafya gibi unsurların katkıda bulunduğunu söylemiştir (Avcığlu, 2011: 363).

Sosyal medya üzerinden gerçek hayatta bulmakta zorluk çekebileceği düşünce arkadaşları ile sürekli iletişim içinde olmak sanal kimliğin sağladığı avantajlardandır. Hem anlaşabileceği bireylerle iletişim içinde olmak, hemde kendi düşünce tarzlarını yaymak amaçlı kullanılan sosyal medya mecreları ve her bir sanal kimlik propaganda aracı olmuştur. Hem düşüncelerin paylaşımı, hem de yayılması olarak sanal dünya kullanılmaktadır. Daha büyük kitlelerle iletişim kurabilen sanal kimlikler sanal ortamdan ayrılamadığı süreçte hem de gerçek dünyadan uzaklaşarak yalnız kalabilirler. Çünki, sosyal ağ kullanıcısı kendisinde gördüğü eksik noktaların sosyalleşme sürecine olumsuz etkide bulunabileceğini düşünmektedir (Özdemir, 2015: 114).

Sosyal medyada aktif olan kullanıcılar toplumda kabul edilmeyen özelliklerini sanal kimliklerinde yansıtmamaktadırlar. Sanal alemin onlara sağladığı anonimlik onlara istedikleri gibi görünlemelerine izin verir. Çevrim içi olmaları ve görünmez olmaları bireyleri sosyal medyanın ilgi çeken tarafıdır. Sosyal medyada kullanılan takma adlarda bu görünmemezliği destekler. Kendi bilgilerine erişimi istedikleri şekilde sınırlayabilmeleri bu gizliliği yürütmektedir.

Bu gizlilik ve özgürlük çevrim içi oyunlarda da kendini göstermektedir. Bu oyunlarda sanal kimlikler arası iletişim hem gizlilik he özgürlük bakımından sınırsızdır. Gerçek hayatta kaybedeceği hayatın, evin, bir eşyanın vereceği kayıp sanal alemde hissedilmemektedir ve ciddiye alınmamaktadır. Örneğin, gerçek hayatta yüksek hızla kullanılan arabanın yaratabileceği risklerin sanal hayatta olmaması, savaş halinde farklı tatkiklerin kullanılması hayati risklerin sanal savaş oyunlarında olmadığı bireylerin bu ortamlarda daha rahat olduklarını gösterir.

Başka bir avantaj, sanal dünyada kullanılan dil, ifade biçimleri aynıdır ve farklı dillere ihtiyaç duyulmamaktadır. Caneron Bailey bu durumu kullanıcıların kendilerine "Sanal bir deri giydirmesi" olarak tanımlamıştır (Bailey, 2001: 335-336). Bu görünmezlik özelliği siber zorbalık adlanan davranışın sergilenmesinede yol açmaktadır. Mekan ve zaman sınırlığının olmaması siber zorbalığın artmasına neden olmuştur ki, bu zorbalık bazen gerçek hayatta da kendini göstermektedir.

\section{SANAL GERÇEKLIK KAVRAMI}

Gerçeklik hakkında bildiğimiz her şey duyularımız yoluyla gelir. Tüm gerçeklik tecrübemiz sadece duyusal bilgilerin bir kombinasyonudur ve beynimiz bu bilgiyi algılama mekanizmasıdır. Bu durumda, eğer duyularınızı uydurma bilgilerle sunabiliyorsanız, gerçeklik algısı buna tepki olarak değişecektir. Gerçekte var olmayan bir gerçeklik versiyonu sunulmakta, ancak bakış açınızdan gerçek olarak algılanmaktadır. Sanal gerçeklik olarak adlandırdığımız kavram budur. Sanal gerçeklik internet aracılığı ile yaratılmış bir dünyada karşılıklı iletişimin kurulduğu bir alandır. Katılımcılara gerçeklik hissi veren bir ortamdır. Bu ortam gerçek hayatın ötesinde bir ortamdır. Bu alanı Wiliam Gibson “cyberspace” (Gibson, 1984 : 77), “siberuzay” olarak adlandırmıştır. Bugün sanal gerçeklik genellikle bilgisayar teknolojisi kullanılarak uygulanmaktadır. Kulaklıklar, gözlükler ve başka özel nesneler gibi bu amaçla kullanılan sistemler vardır. $\mathrm{Bu}$ nesneler gerçekliğin yansımasını yaratmak için duyularımızla beraber hayata geçirilmek için kullanılmaktadır. Gerçekte yapması zor, pahalı, tehlikeli olan her şey ekran arkasında yapıldığı zaman sanal gerçeklik kavramı ortaya çıkarmaktadır.

Siberuzay - bilgisayar ağları vasıtasıyla dijital ortamda enfarmasyon paylaşımının yaşandığı bir alandır. Somut bir mekanda oluşmuş bu dünyada var olan gerçeklikte sanaldır. Foucault siber uzay kavramını açıklarken ütopya ve heterotopya kavramlarını kullanmıştır. Foucault’a göre ütopya gerçeklikle bağlantısı olmayan bir alandır. Toplumun ütopya ile ters ilişki içinde olduğunu belirtmiş̧ir 
(Foucault, 1984: 295). "Ters" olarak tanımladığı mekanlar aynı yerde olan ve aynı anda tersine çevrilmiş mekanlar olarak anlatmıştır. Örnek olarak buna aynayı göstermiştir. Aynanın, yersiz bir mekan olduğu için yersiz olduğunu söylemiştir. "Ben, aynada kendimi görürüm ama ben gerçekdışı, sanal bir mekanda değilimdir. Ben ordayım, ama orada değilimdir. Ayna, orada olan, beni kendime gösteren bir gölgedir ve bu gölge benim nerede olmadı̆̆ımı görmemi sağlar; aynanın ütopyası budur. Heterotopya olmasının nedeni ise ayna gerçekte var olmaktadır ve var olmamın karşıtı bir haraketi simgeler. Aynanın var olduğu noktadan benim olmadiğım noktay görebilirim" (Foucault, 1984:296). Sanal gerçeklik kavramı da, Foucault’ın anlatmaya çalıştığ 1 gibi insanların kendilerini gördükleri sadece içinde var olmadıkları bir ortamdır. Sanal gerçeklik içinde insanların kendilerini gösterdikleri, kendilerini tanıtdıkları mekanlar dijital oyunlar, sosyal medya mecraları, sohbet odaları gibi mekanlardır. Gerçek dünyada bulunduğu süreç içinde başka bir dünyada bulunabilmek sanal gerçeklik kavramını açıklayabilir.

İlk sanal gerçeklik simülasyonu Morton Heilig tarafından "Sensorama Simulator" adı altında sunulmuştur. Helig hem de kafaya takılabilen bir televizyonun yapılabileceğini düşünerek "Telesphere Mask" adında 3D çevresel görüntü ve ses ile gerçeği simüle edebilen bir maske icat etmiştir (Sarnoff, 1960. Aktaran Bostan, 2007: 89). Sanal gerçekliğin bireylere sağladığı avantajlar dijital dünyada onların kimliklerini abartılmış, hayali, egolarını ve cinsel isteklerini tatmin etmiş, olarak ve dünyada ulaşmakta zorluk çektikleri şeylere ulaşmış olarak sunmasıdır. Baudrillard sanal gerçekliği tuzak olarak göstermiştir. Buna sebep ise var olmayanın var olduğunu göstermesi, gerçeği birebir kopya etmesi olarak belirtilmiştir (Baudrillard, 2010: 15).

Burdea, sanal gerçekliğin bilgisayar grafikleri ile yaratılan gerçek dünyanın kopyası olan ancak statik olmayan kullanıcıdan gelen girişlere cevap verebilen bir dünya simülasyonu olduğunu belirtmiştir (Burdea, 2003: 46). Sanal alemin bize sunduğu avantajlar içerisinde gerçek belleklerin yerini almış olan sanal bellek - bulut (cloud) önem taşımaktadır. Var olan verilerin toplanarak sanal bir alemde korunması ve arşivlenmesi enformasyonun gerçek dünyaya paralel olarak dağılımını sağlar. Bulutun topladığı veriler her zaman var olan, doğru bilgiler değildir. Bireylerin hayatlarının her anını değil, sadece belirli dönemlerini sanal dünyaya simüle etmeleri sanal dünyada ortaya çıkan kimliklerin gerçek kimlikler değil, sanal dünyaya simüle edilmiş kimlikler olduğunu söyleyebiliriz.

Teknolojinin gelişimi ve internetin ortaya çıkması ile ekranlara bağlı yaşamları anlatan Black Mirror (Siyah ayna) dizisinin Be Right Back (Hemen Dön) adlı bölümünde buluta yüklenen verilerle gerçek hayatta sanal olan bir kimliğin ortaya çıkma süreci anlatılmaktadır. Filmde simülasyon olan gerçek izlenimi yaratabilen bir bilgisayar programı anlatılarak, gerçek veya sahte olması konusunda sorular yaratılmıştır. Gerçek hayata simüle edilmiş illüzyonun gerçek veya yansıma olduğu tartışılır. Gerçeğin sahteye dönüşmesi, sahtenin gerçeğin yerini almış olduğunu göstermez ve bu sadece bir yansımadır. Sahte gerçeklik konusunu merkez alan film Black Mirror, genel olarak film yapısında gerçek ve sanal alemi karşılaştırmalı olarak kullanmıştır. Başaran`ın söylediği gibi, filmde de, dijital teknolojiler gerçeğin önünü keserek kendi simülasyonlarını yaratmışlardır (Başaran, 2007: 136).

Filmde gerçeğe benzer ama sahte yaşanan bir dünya açılanmaktadır. Bulutta toplanan verilere göre insanın ikizi yaratılmıştır. Baudrillard bu durumu yaşantımızda eski gerçekliğin yerini yeni bir simülasyon ilkesinin aldığını söyleyerek açıklamıştır. Film üzerinden sanal ve geçek alemi karşılaştırırsak, yapay bilinçin gerçek bilinç gibi var olabilme süresinin Bostromun ’da söylediği gibi sadece fişe bağlı olduğu süreçlerdir. Bunun sebebi insanların beyine sahip olmasıdır. Yapay zeka sadece matematik sembollerden oluşmaktadır ve sadece verilen komutlara uymaktadır. Ruh, his, duygu gibi kavramlar yapay zekalarda bulunmamaktadır ve bu gerçek zekadan farkıdır.

\section{BLACK MIRROR (SIYYH AYNA) DIZIISININ BE RIGHT BACK (HEMEN DÖN) ADLI BÖLÜMÜNDE GERÇEK VE SANAL DÜNYA}

Be Right Back bölümü, genel olarak hem geleceğin hem de teknolojiyle olan ilişkimizin ne hale gelebileceğinin bir göstergesidir. Ayrıca teknoloji ile olan ilişkimizin 20. yüzyılın ortalarından beri nasıl değiştiğini de göstermektedir. Bu bölüm, günümüz dünyasındaki birçok konu ile ilgili soruları gündeme getirimektedir. Filmde, eşi Ash'in (Domhnall Gleeson) kazaya uğramasından ve yeni bir 
teknoloji ile tanıştıktan sonra Martha'nın hayatının (Hayley Atwell) değişimi tasvir edilimektedir. Bu hizmet, çevrim içi sosyal ağ etkinliklerinden elde edilebilecek materyali ve daha sonra yaptığı özel mesajlar ve Martha'ya yapılan aramaları temel alarak çevrim içi mesajlar ve telefon görüşmeleri yoluyla Ash'i taklit eden bir yazılım paketidir. Gösteri, Ash'in tam gövdeli bir taklidiyle donanıma geçtiğinde daha da soğuk bir etki yaratmaktadır. Martha eşinin kaybından sonra yeni teknoloji ile uğraşırken onu eski yaşantısından uzaklaştıran bu teknolojinin sadece bir taklit olduğunu da anlamaktadır. Bu teknoloji Ash in gerçek kişiliğini sosyal medya sitelerinde sergilediği bilgilere göre taklit eden bir teknolojidir. Geriye kalan duygu, samimiyet ve herhangi anlam taşıyan şeylerden uzak bir kişilik yaratmıştır.

Filmde anlatılmak istenen sanal dünya iletişiminin gerçek ilişkiler veya insan etkileşiminin yerini alamamasıdır. Teknolojinin birçok boşluğu kapatabilmesi, ancak kişisel yakınlık veya dostluk arasındaki boşluğu kapatamaması anlatılmaktadır. Daha önemlisi toplumun teknoloji ile olan ilişkisini, aynı zamanda aşırılılıklar hakkındaki korkuları temel alan muhafazakarlığı anlatmaktadır. Teknolojik değişim ve büyüme her zaman insanların hayatlarında radikal bir gelişme ile bağlantılı iken, bu ilişki, hayatımızın belirli yönlerini koruyamadı. Örneğin, facebook var olan arkadaşlarla bağlantıları sürdürülmesi için tasarlanan bir ağdı. Sonradan çevrim içi arkadaşlıklar kurulan bir ortam olmaya başlamıştır. Akıllı teknolojiler milyonlarca insanın şu anda dünyada var olan inanılmaz miktarda bilgiye erişmesine izin vermektedir. Ash, aktif sosyal medya kulanıcısı olan ve sosyal medyayı "insanları eğlendiren bir platform " olarak adlandıran bir karakterdir. Onun sosyal medyada oluşturduğu karakter gerçek hayatından zamanını ve gerçekleştireceği eylemleri çalmaktadır. Karısına karşı bile ilgisiziliğinin sebebi hayatının gerçek ve sanal olarak ikiye bölünmesidir. Gerçek hayattan uzaklaşarak sanal hayatta kendisini kaybetmektedir ve simülasyon içinde yaşamaktadır. Baudrillardın`da söylediği gibi, "yalnızca hayal edilen ütopya, kaybedilen bir nesnenin hayalini kurmaktadır" (Baudrillard, 2001: 85).

Eşinin ölümünde dijital ortamı suçlu bulan Martha, yeni teknoloji sayesinde artık kocasının kendi bilgileri üzerinden ortaya çıkmış taklidi ile görüşme imkanını kazanmaktadır. Ash in sosyal medyada paylaştığı bilgiler aracılığ 1 ile ortaya çıkmış gerçek olmayan bir kişiliğinin sadece gerçeğinin avantajlı taraflarını kendinde toplaması ile sosyal mecrelarda yer alan paylaşımların gerçek kişiliği tamamen yansıtmayan bir taklidi ile gerçek hayat da artık onun yerini almaktadır. Hem geçmiş, hem süren hayatında, karakterinde var olan olumsuz davranışlarını saklamak için sosyal ağlarda kendi ile ilgili sadece göstermek istediği bilgileri sunarak farklı bir kişilik oluşturmuştur ki, ölümünden sonra gerçek hayata yansıyan sanal kimliği de kötü özelliklerinden arınmış, sadece olumlu yönlerini gösteren bir kimlik olarak ortaya çıkmıştır. Başlangıçta anlık ileti gönderen, daha sonra telefonda Martha ile konuşan kopya, kendi kendine haber vericidir. Ash'i tamamen değiştiremeyeceğini ve parametrelerinin bir bilgisayar programı olduğunu bilmektedir.

Turingin 1950 y1lında "Computing Machinery and Intelligence" adlı makalesinde "Ĕ̆ger bir makine karmaşıksa, sözlü tepkileri bize bir insanla etkileşim kurduğumuzu düşünmemize yol açarsa, bunun bir insan gibi akıllı olduğu sonucuna varabiliriz " (Turing, 1950: 450) düşüncesinin Black Mirror dizisinin "Be right back" adlı bölümündeki gerçek insan gibi düşünebilen bir makine için çok uygun olduğunu görebiliriz. Gerçek Ash`den farklı olarak Ash in sanal taklitinin önemli görevi Martha ya dikkat ve itaat etmektir. Eşinin dijital ortamlarda kayıp olarak gösteremediği bu özelliklerin taklitininde bulunması kişinin kendini dijital ortamda yansıtması ile bağlıdır. Kişilerin farklı karakterlere sahip olduğu gerçek dünyada sadece programlanmış olan bir karakterin sadece bir makine olduğu bilinmektedir.

Filmde gerçek dünya ve sanal dünya arasındaki farkın en önemli özelliği gerçek Ash`le taklidi arasındaki büyük boşluk farkıdır. Yapay zeka ve insan arasındaki düşünebilme ve hissetme farkı, aradaki boşluğun başlıca sebeplerindendir. Filmde Martha'nın telefonu düşürdüğü an paniklemesi sanal dünyanın sadece internete bağlı olarak sürdürülmesini gösterir. "Seni elimden düşürdüm" diyerek, onun gerçek olmadı̆̆ını göstererek onu bir nesneye bağlamaktadır. Bu nesne orjinalinden farklı olarak kopyalana, artırılabilmektedir. Yapay zeka gerçek zekanın bir kopyasıdır. Her gün daha fazla enformasyon yüklenebilen gerçek değişe ve gelişebilmektedir. 
Araştırmanın genel amacı sanal ve gerçek dünya arasındaki farkı araştırmaktır ki, filmde bu Ash in ölümü ile sahte bir kopyasının ortaya çıkması ile gösterilmektedir. Ilk olarak Martanın programın Ash 'in bilgilerine erişmesine izin vermesi ile başlar. $\mathrm{Bu}$, yapay zekanın sadece sosyal medyaya yüklenmiş bilgiler doğrultusunda ortaya çıkdığının göstericisidir. Bu, yapay zekanın her zaman ideal bir benlik olarak ortaya çıkmasını göstermektedir. Filmde anlatmaya çalştığımız yapay ve gerçek arasındakı farklar ölü Ash`ın yeniden yaratılması ile öne çıkmaya başlar. Bilgilerin, ruhun ve zihnin yerine geçerek yarattığı yapay zeka sadece internete bağlı olarak yaşamını sürdürmektedir. Ash'in bu sahte kopyası gerçekliğin ve orjinalliğinin sadece gerçeğe ait olduğunu göstermektedir. Sahte ve gerçek arasındaki farkı gösteren diğer bir sahne sahte Ash `in Marta`nın isteklerini uygulamak üzerine tasarlanmış olmasıdır. Bir bilgisayar programı olarak sahte Ash in sadece emirler üzerine eylemler gerçekleştirmesi onun gerçek insandan farklı olarak kendi kararlarını verme ve düşünme becerisine sahip olmadığını göstermekedir. Gerçek insandan farkı duygu ve düşüncelerinin olmamasıdır. Gerçek bir insanın sadece hiss ederek hayata geçirdiği eylemi, yapay zeka sadece belirtilen emirler olarak hayata geçirmektedir.

Filmin ilk sahnelerinde Ash teknolojiye bağımlı olan bir birey olarak gösterilmiştir. Bu bağımlılık onun etrafinda olub bitenle ilişkisini keşmiş ve hatta sevdiklerine karşı ilgisiz bir duruma getirmiştir. Sanal dünyada yaşadığı sanal hayata ve büründüğü sanal kimliğe bağl1lı̆̆1 onu gerçek kimliğinden ve gerçek hayatından uzaklaştırmıştır. Gerçek hayatın farkında olmaması karşılaşacağı risklerin ciddiyetinin de farkında olmadığını göstermektedir. Bu dikkatsizliği sonucunda araba kazası geçirir ve dünyası değişir. Hikayenin dönüm noktası Ash`in kaza geçirerek dünyasını değişmesinden sonra Marta 'nın programla tanışması ile başlar. Gerçek Ash 'in yarattığı sanal dünyada olan sanal kimliğin gerşek hayata simule edilmesi ile sahte kimlik gerçek hayatla buluşur. Gerçek hayatla buluşmadan sonra artık saht ile gerçek arasındaki farklar görülmektedir. Gerçek Ash in olumsuz yönlerinden arınmış sahte Ash artık ideal bir Ash olarak Martanın hayatında yaşamaya devam etmektedir. Gerçek Ash ten görünüş olarak farkı olmayan simülasyonun gerçek olmadığını anlayan Marta artık gerçek ve sahte arasındaki farkları görmektedir. Aşağdakı tabloda gerçek Ash `i sahte kimliğinden ayıran başlıca özellikler yer almaktadır.

TABLO 1. Gerçek Ash `i sahtesinden ayıran özellikler

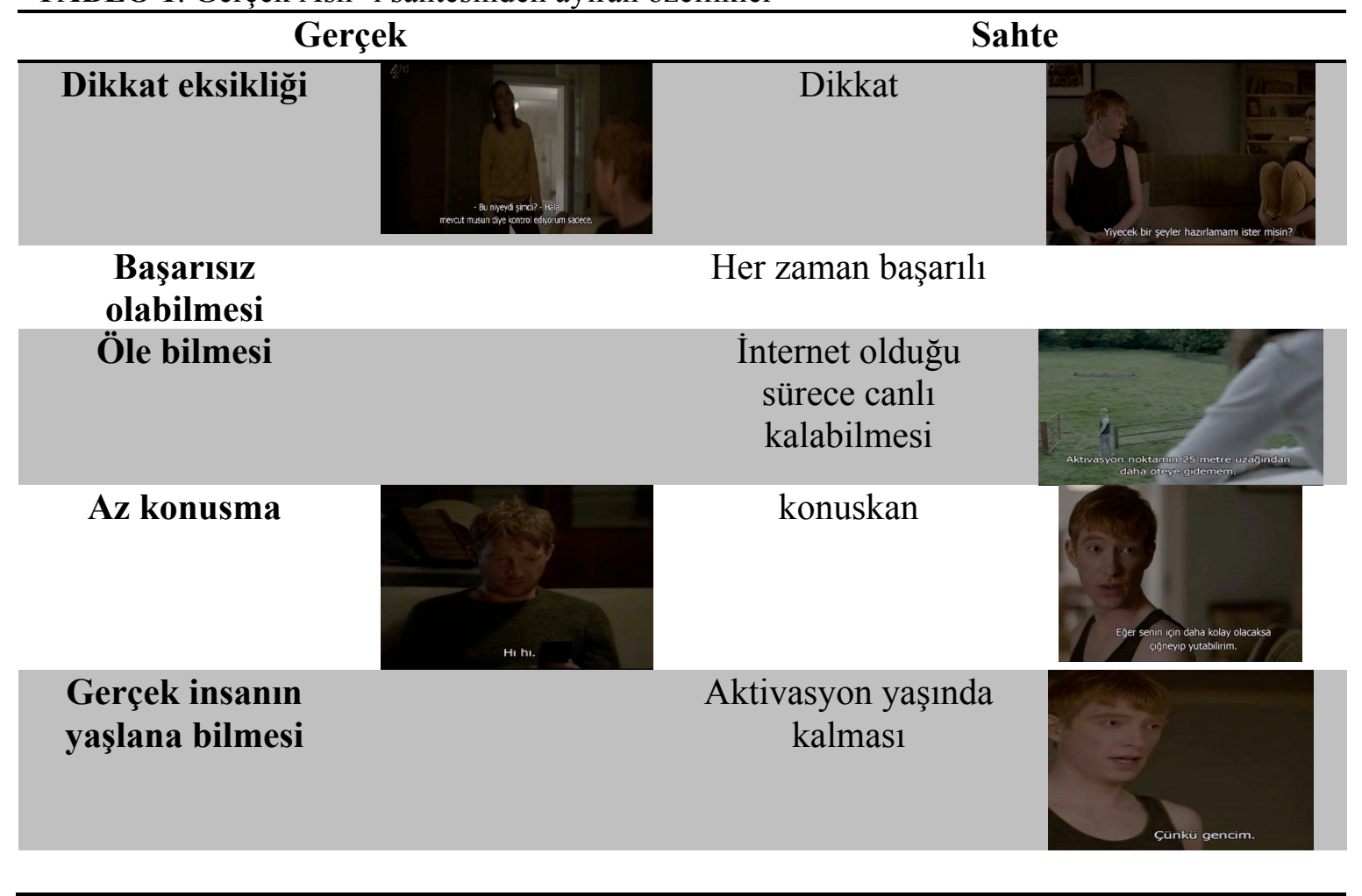


Elimizdeki nesneye ne kadar çok, fotoğraf yüklersek, sosyal paylaşımda daha başarılı olmaktayız ve gerçek hayatta sosyal olup olmamız bunu değiştirmemektedir. Ancak, gerçek hayatta ve İnternet'te sosyalleşmenin nitelikleri, simülasyon ve gerçek yaşam ikilemi nedeniyle farklı kavramlara sahiptir. Sahte Ash gerçek Ahs`in göstermek istediği bilgilere sahiptir, ve Ash in gerçek karakteri ile ilgili bilgisi yoktur. Marta ile güzel sohbet eden sahte Ash'in iletişim zekasına sahip olduğunu göstermektedir. Ash 'in sesi ile konuşan, görüntüsünü veren yapay zeka Ash'in isyankar veya benzersiz karakterini tam olarak taklit edemez. İnsan olarak organik, ancak yapay, yaratılış olarak programlanmış bir insandır. Biyolojik açıdan mükemmel olsa da, Ash'in günlük yaşam aktiviteleri ve anıları eksiktir. Yukarıda anlattıklarımızdan gerçek ve sahte Ash arasındakı farklılıkları, simülasyonu gerçekten ayıran temel özellikleri aşağdaki gibi sıralaya biliriz:

TABLO 2. Filmde gösterilen sanal ve gerçek kimlik arasındaki farklar.

\begin{tabular}{|c|c|}
\hline GERÇEK & SANAL \\
\hline $\begin{array}{l}\text { Hem zayıf, hem güçlü noktaları ile hayatını } \\
\text { sürdürmesi }\end{array}$ & $\begin{array}{c}\text { Sosyal Medyada belirtilen özellikler ve } \\
\text { gösterilmesi istenen noktaları benimseyerek } \\
\text { yaşam sürdürmesi }\end{array}$ \\
\hline Kendi kararını verebilme becerisi & $\begin{array}{l}\text { Karar verme sürecinin sadece } \\
\text { programlaştırılmış olarak belirlenmesi ve } \\
\text { emirlere uyarak devam ettirilmesi }\end{array}$ \\
\hline $\begin{array}{l}\text { Sadece insanlara ait olan duygulara sahip } \\
\text { olması }\end{array}$ & $\begin{array}{c}\text { Hiçbir duyguya sahip olmaması, sadece doğru } \\
\text { olarak belirlenmiş hareketlerin } \\
\text { gerçekleştirilmesi }\end{array}$ \\
\hline $\begin{array}{l}\text { İletilen emirlere karşı çıkabilme, hayır } \\
\text { diyebilme }\end{array}$ & $\begin{array}{l}\text { Sadece verilen emri uygulamak için } \\
\text { tasarlanmas1 }\end{array}$ \\
\hline
\end{tabular}

Görüldüğg̈ gibi, görünüşte hiç bir fark görmediğimiz sahte ve gerçek kimlik arasında büyük fark vardır ki, bunun en önemlisi gerçek insanın internete, elektriğe bağlı olmadan yaşayabilme özelliğidir.Sanal dünyanın sadece internete bağlı kalarak var olması, bu dünyayı gerçekten ayıran önemli özelliktir.

\section{SONUÇ}

Çalışmada modern dünya teknolojileri ile gelişen farkl1-sanal bir dünya ve bu dünyada dönüşen kimlikler anlatılmıştır. Bu sanal dünya gerçek olmasa da, bireylerin içinde var olabilir ve kendi yaşam ve karakterlerini biçimlendirebilirler. Bu dünyanın sunabileceği imkanların sınırsız olması sanal dünyayı daha ilgi çekici yapabilmektedir. Sanal dünyanın büyümesi gerçek dünyayala arasındaki bazı farkların bireylerin gözünde kaybolmasına, gerçek ve sahte kavramlarının arasındakı sınırların yok olmasına yol açmıştır. Baudrillard, sahte ve gerçek arasındaki sınırın kaybolmasını sudakı yansımasına aşık olan Naarkissos`a benzetmiştir (Baudrillard, 2002: 85). Sanal dünyanın vatandaşları da bu dünyada yarattıkları ideal kimliklerden büyülenmişler ve bu dünyanın içinde kayıp olmuşlar.

Araştırmanın sonunda sanal dünyada kimlik dönüşümünün incelenmesi sebebinin ideal bir kimliğe sahip olmak ve dış dünyanın kısıtlamalarından uzaklaşmak olduğunu görebiliriz. Sanal dünyaya kolay adapte ola bilme sebeplerinin de bu söylenenler olduğunu açıkca görmekteyiz. Kolay adapte süreci ve sınırlarsız yaşam süreci sanal dünyanın sunduğu imkanlardandır.

Sanal gerçeklik, duyularımıza sanki orada olduğumuz gibi yaşanacak bir sanal ortamın yaratılmasıdır. $\mathrm{Bu}$ amacı gerçekleştirmek için bir dizi teknolojiyi kullanır ki, buda algı ve duyularımızı hesaba katması gereken teknolojidir. Hem eğlenceye hem de ciddi kullanımlara sahiptir. Teknoloji zaman geçtikce ucuzlamaya veyaygınlaşmaya başlamıştır. Gelecekte teknoloji için çok daha yenilikçi kullanımlar ve belkide sanal gerçeklik imkanları sayesinde iletişim sürecimizi daha ilerletmemiz beklenebilinir. Çalışmada incelenen Black Mirror dizisinin "Be right back" bölümünde gösterilen sanal dünya ve gerçek dünya arasındakı sınırlar açıklanmış ve bu iki dünyanı birbirinden ayıran 
farklılıkların yarattığı boşluğun sebebi açıklanmıştır. Bu farklılıklar gerçek insanın bir bilgisayar programından ibaret olmadığını, düşünerek, hissederek aldığı kararları uygulayarak yaşadığını göstermektedir. İletişim sürecinde aktardığı bilgilerin kendi tecrübeleri, istekleri ve yaşantıları doğrultusunda tecrübe ettiği ve anılarında sakladığı bilgiler olduğunu görmekteyiz. İnsanların sadece belirli koşullarda emir alarak uygulayabildiği eylemler vardır.

Filmde yaratılmış sahte kişinin anılarının sadece paylaşılmış bilgilerden oluştuğunu görmekteyiz. Verilen kararların sadece programlanmış olması ve sadece Marta’nın emirlerine uyma gibi programlaştırılması sanal ve gerçek arasındaki bu boşluğun sebebini göstermektedir. Bu teknolojinin, bu insanın verilerini kullanarak bir insanı tam olarak kopyalayamayacağı anlamına gelir. Her gün devam eden gelişim sonucunda filmlerde gösterilen bu kurguların hayal ürünü olduğunu düşünmemiz yanlış olur. Devam eden araştırmaların küçük bir yansıması olan bu filmler gelecekle ilgili bize bilgiler aktarmaktadır. Filmde oluşturulan yapay bilinç ve yapay insan kontrol altında tutulan bir evrenin kanıtı olabilir. Çalışmamızda görüldüğü gibi internetin ve sosyal medyanın kullanımı teknolojinin artık yaşamımızı ölümsüzleştirilmeye doğru ilerlediğini görmekteyiz. Filmde başarılı olanın teknoloji değil insan olduğu gösterilmektedir.

Araştırmanın sonunda filmin ana fikrinin sadece yapay zeka üretimi ile ilgili olmadığını, artık zor olanın başarılması ve istenilen her şeyin elde edilmesi kolaylığının sağlandığı olduğunu söyleyebiliriz. Kişilerin ölümü yenme arzusu teknoloji ile artık mümkün olabilir. Yeni dijital teknolojiler şüphesiz kültürü değiştireceğinden, bunların eleştirileri Black Mirror teknolojileri bugün yaşayan bireyler için son derece uygundur.

\section{KAYNAK:}

Avcloğlu Gürcan, (2011) "Yapısal kimlikten seçimlik kimliğe; kimliğin medya aracıllğgyla yeniden üretimi”. Uluslararası Insan Bilimleri Dergisi, Cilt 8, sayı:2

Bailey, Cameron (2001). "Virtual Skin: Articulating Race in Cyberspace." Reading Digital Culture. David Trend (der.) içinde. Oxford: Blackwell: 335-336.

Baudrillard Jean, Şeytana Satılan Ruh, Doğubatı Yayınları

Baudrillard Jean, (2002) 'Violence of the Virtualand Integral Reality". Ubishops.ca erişim tarihi Mart 2013

Baudrillard, J. 2001. (1979). "Baştan çıkarma üzerine". İstanbul Ayrıntı yayınları.

Baudrillard, Jean. (2010), Nesneler Sistemi, çev. Ŏguz Adanır-Aslı Karamollaoğlu, İstanbul, Boğaziçi Üniversitesi Yayınevi.

Başaran, T. (2007). Soğuk Savaş Sonrası Bilim Kurgu Sinemasında Distopik Sistemler Ve Kontrol Mekanizmaları, Ankara Üniversitesi Sosyal Bilimler Üniversitesi Yayınlanmamış Yüksek Lisans Tezi. Ankara.

Burdea, G. \& Coiffet, P. (2003). Virtual Reality Technology. John Wiley \& Sons

Bostan Basbaros (2007)., Sanal gerçeklikte etkileşim, doktora tezi, Marmara Universitesi Sosyal Bilimler Enstitüsü

Debord, Guy (2006). Gösteri Toplumu. Ayşen Ekmekçi, Okşan Taşkent (Çev.), (2. Baskı). Istanbul: Ayrint.

Deleuze Gilles (2014) Felix Guattari, What is philosophy, Columbia Üniversitesi.

Gibson, W. (1984). Neuromancer. İstanbul:Altıkırkbeş basın yayın

Geray, H. (1995) Küreselleşme ve Masaüstü Sömürgecilik: Yeni Dünya Düzeninde İletişimAğlarl,

Mürekkep , 3 (4), Ankara, 33-46.

Goffman, E., (2004) Günlük Yaşamda Benliğin Sunumu, Metis Yayınlarl, 29,.

Foucault, M (1984). "Of other Space". Foucault. İnfo erişim tarihi: Kasim 2013 http://foucault.info/documents/heterotopia/foucault.heterotopia.en.html

Marx, K. (1844/1993) 1844 El Yazmalarl, Çev: Kenan Somer, Ankara: Sol.

McQuail, D., Windahl, S., (2010). Iletişim Modelleri, İmge Kitabevi Yayınları.

Özdemir Z.(2015), "Sosyal medyada kimlik inşasında yeni akım: Özçekim kullanımı”.Maltpe universitesi İletişim fakültesi dergisi, 2(1). 112-131

Özer Nurı Paşa (2011), Gazete Haberlerinde Manipülasyon: 28 Şubat Örneği, yüksek lisans tezi, Konya 
e-Journal of New Media / Yeni Medya Elektronik Dergi - eJNM September 2017 Volume 1 Issue 3

Wellman, B. ve Wortley, S. (1990). Different Strokes from Different Folks: Community Ties and Social Support. American Journal of Sociology.

Tajfel, H. ve Turner, J. C. (1986). The social identity theory of intergroup behavior. In S. Worschel ve W. G. Austin (Eds.), Psychology of intergroup relations. Chicago: Nelson-Hall.

Turing, A. M. (1950). Computing machinery and intelligence. Mind, 433-460.

Yengin, D.(2015). Yeni medya, Dokunmatik Toplum. İstanbul: Derin yayınlarl.

Yengin, D. (2017). İletişim Çalışmalarında Araştırma Yöntemleri ve Uygulamaları, İstanbul: Der Yayinlart. 